\title{
Rumex obtusifolius is a wild food plant with great nutritional value, high content of bioactive compounds and antioxidant activity
}

\author{
William Gustavo Sganzerla*, Rodolfo Schmit, Mayeve Didomenico Melo, Mônia Stremel Azevedo, \\ Paula laschitzki Ferreira, Ana Paula de Lima Veeck, Jocleita Peruzzo Ferrareze
}

Federal Institute of Education, Science and Technology of Santa Catarina, Lages, Santa Catarina State, Brazil

\section{A B S T R A C T}

\begin{abstract}
Few studies were performed with wild plants, and researches are important to plants valorization and conservation. In this work we evaluated the nutritional composition, bioactive compounds and antioxidant activity of an unconventional food plant, mostly considered as a weed (Rumex obtusifolius). All the analyses were performed in leaf and root: moisture, ashes, lipids, proteins, carbohydrates, $\mathrm{pH}$ and total acidity. Phenolic, flavonoids, flavonols, antioxidant activity (DPPH, ABTS and FRAP) were quantified in aqueous, ethanolic and hydroethanolic extracts. Results show that hydroethanolic extract from root presented more bioactive compounds $(p<0.05)$ and more antioxidant activity by ABTS and FRAP assay; ethanolic and hydroethanolic extract from root presented non-significant difference ( $p>0.05$ ) by DPPH assay. Pearson's correlation coefficients proved that antioxidant capacity is related to the presence of bioactive compounds in the root and leaf of Rumex obtusifolius. Using principal component analysis the extracts were classified in tree groups according to extraction potential, been the root hydroethanolic and ethanolic extracts the highest. This unconventional spread worldwide plant presents a great content of nutritional composition and has the potential to be used in human consumption, providing nutrients and bioactive compounds with high antioxidant activity.
\end{abstract}

Keywords: Rumex obtusifolius; Unconventional food plant; Bioactive compounds; Antioxidant capacity; Principal component analysis

\section{INTRODUCTION}

Approximately 200 species of the genus Rumex are distributed worldwide (Vasas et al., 2015). Rumex obtusifolius belong to Polygonaceae family, and it is native of the Central and Southern Europe mountains. This plant has long been used in folklore medicine as a medicinal herb. In this way, Rumex obtusifolius presents therapeutic indications, because the use cleanses toxins, has laxative, diuretic, calming effect, decrease the incidence of chronic skin diseases, liver disorders and anemia (Gulshan et al., 2012; Carnero et al., 2014).

In Brazil Rumex obtusifolius it is considered as an unconventional food plant, with simple leaves, length from 10 to $18 \mathrm{~cm}$ and high from 6 to $120 \mathrm{~cm}$ (Kinupp and Lorenzi, 2014; Kinupp and Barros, 2007). However, in Europe, Rumex acetosa and Rumex acetosella are components of the diet (St'astná et al., 2010; Harshaw et al., 2010). According to Kinupp and Lorenzi (2014), the edible portion of the Rumex obtusifolius are the leaves, and can be eaten raw as a salad, or cooked in sautéed, puree, cream and soups.

Although, Brazilian flora presents a rich biodiversity, but few species are considered to the human consumption, and there are few researches confirming the potential of Rumex obtusifolius as food and the human consumption is not widespread (Holm et al., 1977; Benvenuti et al., 2001). However, the specie is considered a weed widely distributed and infests grassland and arable lands, and the control is generally performed with chemical herbicides considered toxic and dangerous to the environment, that includes metsulfuron methyl ${ }^{\circledR}, 2.4-\mathrm{D}$ paraquat $^{\circledR}$ and glyphosate ${ }^{\circledR}$ (Nieweglowski Filho et al.,2014).

A new alternative to this plant, to decrease the use of the toxic herbicide, is investigating the food potential, and

\footnotetext{
${ }^{*}$ Corresponding author:

William Gustavo Sganzerla, Street Heitor Villa Lobos, 222, Lages, Santa Catarina, 88506-400, Brazil. Tel.: +55 4932214200

E-mail: sganzerla.william@gmail.com

Received: 02 February 2019; $\quad$ Accepted: 14 April 2019
} 
developed new natural products to the world population. In this way, scientific researchers are important to plants valorization and conservation (Barreira et al., 2015; Šola et al., 2018). Studies concluded that Rumex obtusifolius present antibacterial activity against Escherichia coli (Harshaw et al., 2010), and procyanidins were isolated and classified from Rumex obtusifolius (Spencer et al., 2007).

However, few scientific studies were accomplished about food potential and antioxidant activity in unconventional wild plants. Biologically, substances found in plants are reported as responsible for providing benefits to human health (Liu, 2004). Compounds that are produced in the plant secondary metabolism and are known as bioactive compounds, such as, carotenoids, phenolic, flavonoids, tannins, anthocyanin and others (Rufino et al., 2010; Thilakarathna and Rupasinghe, 2012; Oladeji and Adelowo, 2017; Sganzerla et al., 2018).

Based on these facts, the aim of this work was to accomplish a characterization of an unconventional wild plant (Rumex obtusifolius), evaluating the nutritional composition, bioactive compounds (phenolic, flavonoids and flavonols) and antioxidant activity (DPPH, ABTS and FRAP).

\section{MATERIAL AND METHODS}

\section{Plant material}

Samples of Rumex obtusifolius were identified and collected in the experimental organic area from Federal Institute of Education, Science and Technology of Santa Catarina State (Lages City, Santa Catarina State, Brazil), in the second semester of 2017. The plant was registered at Lages Herbarium of the University of Santa Catarina State (LUSC, UDESC) under the voucher number 10196, corresponding to the taxonomic classification of Rumex obtusifolius. After the harvest were separated the leaves from the roots, washed with water, homogenized in domestic multiprocessor and stored in an industrial freezer $\left(-18 \pm 1^{\circ} \mathrm{C}\right)$. With the fresh samples, extracts were performed using aqueous, ethanolic and hydroethanolic solution $(1: 10 \mathrm{w} / \mathrm{v})$, according to a methodology previously published (Sganzerla et al., 2018).

\section{Proximate composition}

The moisture $\left(105^{\circ} \mathrm{C}, 24\right.$ hours) (method 934.06$)$ and ashes $\left(550^{\circ} \mathrm{C}, 12\right.$ hours) (method 923.03$)$ content was determined according to Association of Official Analytical Chemistry (AOAC, 2006). Protein quantification (method 990.03) was determined according to the methodology of Micro Kjeldahl (AOAC, 2006). Total lipids were determined by cold extraction (Bligh and Dyer, 1959). Total carbohydrates were calculated by the difference among others compounds [carbohydrates $=100-($ moisture + ashes + lipids + proteins)]. Total acidity was determined by titration with sodium hydroxide $\left(\mathrm{NaOH} 0.1 \mathrm{~mol} \mathrm{~L}^{-1}\right)$ until reaching pH 8.1 (Instituto Adolfo Lutz, 2008), and the results were expressed as g of citric acid per 100 grams $\left(\mathrm{g} 100 \mathrm{~g}^{-1}\right)$. The $\mathrm{pH}$ was measured with a digital $\mathrm{pH}$ meter previously calibrated.

\section{Bioactive compounds quantification}

Total Phenolic Compounds (TPC) concentration was determined by Swain and Hillis (1959) with modifications. Total Flavonoids Compounds (TFC) was determined according to Zhishen et al. (1999) with modifications. Total Flavonols (TF) was determined according to Kumaran and Karunakaran (2007) with modifications.

\section{Antioxidant activity determination}

Antioxidant activity was determined through the removal of the free radical DPPH (2.2-Diphenyl-1-picrylhydrazyl) (Brand-Williams et al., 1995), removal of the free radical ABTS (acid 2.2'-azino-bis(3-ethilbenzotiazolin-6-sulfonic) (Re et al., 1999) and through Ferric Reduction Antioxidant Power (FRAP assay) (Benzie and Strain, 1996; Arnous et al., 2002). Trolox was used as standard for the calibration curve and the results were expressed as mg of Trolox Equivalent Antioxidant Capacity (TEAC) per 100 gram of root or leaf in fresh matter (mg TEAC $\left.100 \mathrm{~g}^{-1}\right)$. All analyses of antioxidant activity are described in a previously work published by authors (Sganzerla et al., 2018).

\section{Statistical analysis}

Proximate composition, bioactive compounds and antioxidant activity results were analyzed by Analysis of Variance (ANOVA) and the differences between the means were determined by the Tukey's test $(p<0.05)$. Then, Pearson's correlation coefficient $(r)$ was determined between bioactive compounds and antioxidant capacity by two significance levels $(p<0.05$ and $p<0.01)$. Cluster Analysis (CA) and Principal Component Analysis (PCA) were used to observe interrelationships between solvent extractor. All the statistical process was developed using Statistica ${ }^{\circledR} 7.0$ software (StatSoft Inc., Tulsa, OK, USA).

\section{RESULTS AND DISCUSSION}

Nowadays, vegetables usually consumed were replaced for few cultures considered suitable for large-scale cultivation (Campos et al., 2018). There are several studies demonstrating the potential for consumption of various species considered wild or unconventional food (Mohammed et al., 2016; Bharucha and Pretty; 2010; Chivenge et al., 2015) and Rumex obtusifolius is among these 
plants with excellent nutraceutical properties. The leaves can be eaten raw in salads or cooked and be used in dishes such as purees, creams or soups. In this study, Analysis of Variance (ANOVA) showed that moisture, ashes, proteins and carbohydrates reveal distribution parametric, and presented statistical difference by Tukey's test $(p<0.05)$ (Table 1). Root of Rumex obtusifolius presented a high

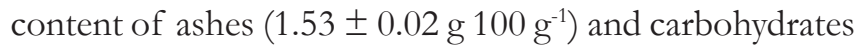

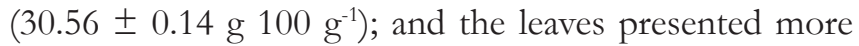

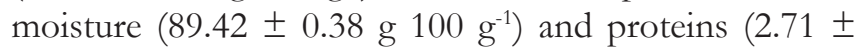

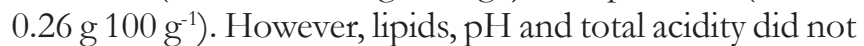
present statistical difference between root and leaf. Studies demonstrated that edible parts of Scolymus hispanicus (Midribs of basal leaves), an unconventional wild plant from Asteraceae family, presented a lower content of proteins

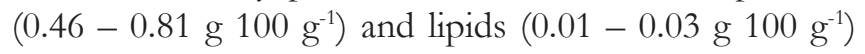
compared with this work (García-Herrera et al., 2014). However, leaves of conventional vegetables (cauliflower, beets and carrots) presents a similar content of lipids and proteins, comparing to the data obtained in this work (Storck et al., 2013).

Root presented more bioactive compounds and antioxidant activity than the leaf of Rumex obtusifolius (Table 2). In general, root hydroethanolic extract was the best solvent tested in this study, with statistical difference $(p<0.05)$ from the other extracts. TPC $(980.95 \pm 1.81 \mathrm{mg}$ GAE $\left.100 \mathrm{~g}^{-1}\right)$, TFC $\left(155.08 \pm 1.83 \mathrm{mg}\right.$ QE $\left.100 \mathrm{~g}^{-1}\right)$ and TF $\left(136.74 \pm 0.78 \mathrm{mg} \mathrm{QE} 100 \mathrm{~g}^{-1}\right)$ were more concentrated

Table 1: Proximate composition on root and leaf of Rumex obtusifolius (fresh matter)

\begin{tabular}{|c|c|c|}
\hline Parameters & Root & Leaf \\
\hline Moisture $\left(\mathrm{g}^{\left.100 \mathrm{~g}^{-1}\right)}\right.$ & $65.91 \pm 0.06^{b}$ & $89.42 \pm 0.38^{a}$ \\
\hline Ashes $\left(\mathrm{g} 100 \mathrm{~g}^{-1}\right)$ & $1.53 \pm 0.02^{\mathrm{a}}$ & $1.39 \pm 0.01^{b}$ \\
\hline Lipids (g $\left.100 \mathrm{~g}^{-1}\right)$ & $0.90 \pm 0.14^{\mathrm{ns}}$ & $0.95 \pm 0.20$ \\
\hline Proteins (g $\left.100 \mathrm{~g}^{-1}\right)$ & $1.11 \pm 0.14^{b}$ & $2.71 \pm 0.26^{a}$ \\
\hline Carbohydrates $\left(\mathrm{g} 100 \mathrm{~g}^{-1}\right)$ & $30.56 \pm 0.14^{a}$ & $5.53 \pm 0.22^{b}$ \\
\hline $\mathrm{pH}$ & $5.36 \pm 0.04^{\text {ns }}$ & $5.19 \pm 0.48$ \\
\hline Total acidity (g citric acid $100 \mathrm{~g}^{-1}$ ) & $0.14 \pm 0.04^{\text {ns }}$ & $0.07 \pm 0.06$ \\
\hline
\end{tabular}

The results are expressed as mean \pm standard deviation. All analyses were performed in triplicate $(n=3)$. Different letters in each line after standard deviation represent a significant difference by Tukey's test $(p<0.05)$. ns: non-significant difference by Tukey's test in hydroethanolic $(70 \%$ ethanol and 30\% water, v/v) extract. In uvaia pulp (Eugenia pyriformis Cambess), the same proportion of hydroethanolic solution was responsible for a higher extraction of phenolic and flavonoids compounds (Sganzerla et al., 2018). Pearson's correlation coefficients (Table 4) shows that TPC presented a positive and significative correlation $(\phi<0.05$ and $p<0.01)$ comparing to TPC/TFC (0.99), TPC/TF (0.98) and TFC/TF (1). Studies demonstrate that these compounds are the majoritarian fraction of plants secondary metabolism, being the main responsible for the antioxidant activity (Rufino et al., 2010; Thilakarathna and Rupasinghe, 2012; Oladeji and Adelowo, 2017).

Many compounds are nutritionally important to the human metabolism, such as proteins, carbohydrates, lipids, vitamins and minerals. However, non-nutritional biologically active or bioactive natural products are also very important to human metabolism. Plant polyphenols are one of the groups of bioactive compounds that have attracted the attention for the functional food characteristics (Liu, 2004; Rufino et al., 2010; Thilakarathna and Rupasinghe, 2012; Clerici and Carvalho-Silva, 2011). Figure 1 presents a short classification of plant phytochemicals, and the compounds marked in bold were evaluated and quantified in this study. Rumex obtusifolius can be considered as a good source of bioactive compounds, because presented a high concentration of phenolic, flavonoids and flavonols, as demonstrated in this study. Furthermore, pulp from fruits, such as, Campomanesia sp. (270 mg GAE $\left.100 \mathrm{~g}^{-1}\right)$,

Table 2: Bioactive compounds on root and leaf of Rumex obtusifolius (fresh matter)

\begin{tabular}{llccc}
\hline Sample & Extract & TPC $^{1}$ & TFC $^{2}$ & TF $^{2}$ \\
\hline Root & Aqueous & $17.05 \pm 0.17^{e}$ & $8.94 \pm 0.45^{\mathrm{e}}$ & $6.48 \pm 0.04^{\mathrm{e}}$ \\
& Ethanolic & $573.18 \pm 23.57^{\mathrm{b}}$ & $108.97 \pm 0.92^{\mathrm{b}}$ & $106.46 \pm 0.38^{\mathrm{b}}$ \\
& Hydroethanolic & $980.95 \pm 1.81^{\mathrm{a}}$ & $155.08 \pm 1.83^{\mathrm{a}}$ & $136.74 \pm 0.78^{\mathrm{a}}$ \\
Leaf & Aqueous & $19.62 \pm 0.18^{\mathrm{e}}$ & $2.72 \pm 0.28^{\mathrm{e}}$ & $1^{\mathrm{a}}$ \\
& Ethanolic & $387.25 \pm 3.63^{\mathrm{c}}$ & $403.78 \pm 2.75^{\mathrm{c}}$ & $359.52 \pm 7.85^{\mathrm{c}}$ \\
& Hydroethanolic & $234.66 \pm 9.06^{\mathrm{d}}$ & $263.52 \pm 2.75^{\mathrm{d}}$ & $217.30 \pm 0.79^{\mathrm{d}}$ \\
\hline
\end{tabular}

The results are expressed as mean \pm standard deviation. All analyses were performed in triplicate $(n=3)$. Different letters in each column after standard deviation represent a significant difference by Tukey's test $(p<0.05)$. TPC: Total Phenolic Compounds; TFC: Total Flavonoids Compounds; TF: Total Flavonols. ${ }^{1} \mathrm{mg}$ of Gallic Acid Equivalent (GAE) $100 \mathrm{~g}^{-1} ;{ }^{2} \mathrm{mg}$ of Quercetin Equivalent (QE) $100 \mathrm{~g}^{-1}$ 
Table 3: Antioxidant activity on root and leaf of Rumex obtusifolius (fresh matter)

\begin{tabular}{llccr}
\hline Sample & Extract & DPPH ${ }^{1}$ & ABTS $^{1}$ & FRAP $^{1}$ \\
\hline Root & Aqueous & $84.05 \pm 5.05^{\mathrm{c}}$ & $67.82 \pm 0.63^{\mathrm{e}}$ & $195.59 \pm 27.79^{\mathrm{e}}$ \\
& Ethanolic & $3311.90 \pm 117.85^{\mathrm{a}}$ & $1859.65 \pm 12.70^{\mathrm{b}}$ & $5704.37 \pm 106.88^{\mathrm{b}}$ \\
& Hydroethanolic & $3800.00 \pm 303.05^{\mathrm{a}}$ & $2695.29 \pm 88.94^{\mathrm{a}}$ & $13579.24 \pm 342.01^{\mathrm{a}}$ \\
Leaf & Aqueous & $32.26 \pm 0.84^{\mathrm{c}}$ & $17.05 \pm 1.27^{\mathrm{e}}$ & $46.22 \pm 2.06^{\mathrm{e}}$ \\
& Ethanolic & $1859.52 \pm 16.83^{\mathrm{b}}$ & $938.72 \pm 6.35^{\mathrm{c}}$ & $2953.46 \pm 106.88^{\mathrm{c}}$ \\
& Hydroethanolic & $1383.33 \pm 50.50^{\mathrm{b}}$ & $633.24 \pm 6.37^{\mathrm{d}}$ & $1472.19 \pm 192.38^{\mathrm{d}}$ \\
\hline
\end{tabular}

The results are expressed as mean \pm standard deviation. All analyses were performed in triplicate ( $n=3)$. Different letters in each column after standard deviation represent a significant difference by Tukey's test $(p<0.05)$. DPPH: 2.2-Diphenyl-1-picrylhydrazyl $\left(\mathrm{C}_{18} \mathrm{H}_{12} \mathrm{~N}_{5} \mathrm{O}_{6}\right)$;

ABTS: 2.2'-Azino-bis (3-ethylbenzothiazoline-6-sulfonic acid) $\left(\mathrm{C}_{18} \mathrm{H}_{18} \mathrm{~N}_{4} \mathrm{O}_{6} \mathrm{~S}_{4}\right)$; FRAP: Ferric Reduction Antioxidant Power. ${ }^{1}$ mg of Trolox Equivalent Antioxidant Capacity (TEAC) $100 \mathrm{~g}^{-1}$

\begin{tabular}{|c|c|c|c|c|c|}
\hline \multicolumn{6}{|l|}{ Root $^{*}$} \\
\hline$r$ & TFC & TF & DPPH & ABTS & FRAP \\
\hline TPC & 0.99 & 0.98 & 0.95 & 0.99 & 0.98 \\
\hline TFC & & 1 & 0.98 & 1 & 0.95 \\
\hline TF & & & 0.99 & 0.99 & 0.92 \\
\hline DPPH & & & & 0.97 & 0.87 \\
\hline ABTS & & & & & 0.95 \\
\hline \multicolumn{6}{|l|}{ Leaf* } \\
\hline$r$ & TFC & TF & DPPH & ABTS & FRAP \\
\hline TPC & 1 & 1 & 0.98 & 1 & 0.99 \\
\hline TFC & & 1 & 0.99 & 1 & 0.98 \\
\hline TF & & & 0.99 & 1 & 0.99 \\
\hline DPPH & & & & 1 & 0.96 \\
\hline ABTS & & & & & 0.98 \\
\hline
\end{tabular}

*All the data presented significative correlation to $P<0.05$ and $P<0.01$

Plinia edulis (159 mg GAE $100 \mathrm{~g}^{-1}$ ), Anacardium occidentale (159 mg GAE $100 \mathrm{~g}^{-1}$ ) and Pouteria gardneriana (225 mg GAE $100 \mathrm{~g}^{-1}$ ) (Rocha et al., 2011) that are usually consumed as source of bioactive compounds, presented a low content of total phenolic compounds compared to root and leaf of Rumex obtusifolius.

For the TPC measured by Folin-Ciocalteu method, Vasco, Ruales and Kamal-Eldin (2008) created a classification of three groups: low content of total phenolic $(<100 \mathrm{mg}$ GAE $\left.100 \mathrm{~g}^{-1}\right)$; intermediate content of total phenolic (200-500 mg GAE $\left.100 \mathrm{~g}^{-1}\right)$; and high content of total phenolic (>500 mg GAE $\left.100 \mathrm{~g}^{-1}\right)$. In this study, using water as solvent the root and leaf are classified as low content of TPC, but ethanolic and hydroethanolic extracts from root are consider as high content of TPC. However, ethanolic and hydroethanolic extract from leaf are considered as intermediate source of phenolic compounds.

Studies demonstrate that aqueous extract with high source of antioxidant compounds could acts on oxidative stress, reducing lipid peroxidation in rats (Da Silva et al., 2013). An introduction of a bioactivity extract in vivo could contribute to prevent damage by reactive species (Pereira et al., 2009), and natural plants from Brazilian biodiversity could be used in the food and pharmaceutical industry, because presents high content of bioactive compounds (Oliveira et al., 2012).

Total antioxidant activity by DPPH, ABTS and FRAP assay are shown on Table 3. In general, different solvents extractors presented difference extraction rates for antioxidant activity. Root and leaf from Rumex obtusifolius presented statistical difference $(p<0.05)$. The results demonstrate that hydroethanolic extract from root presents more antioxidant activity by ABTS $(2695.29 \pm 88.94 \mathrm{mg}$ TEAC $\left.100 \mathrm{~g}^{-1}\right)$ and FRAP (13579.24 $\pm 342.01 \mathrm{mg}$ TEAC $100 \mathrm{~g}^{-1}$ ) comparing to the other extracts. Moreover, ethanolic $\left(3311.90 \pm 117.85 \mathrm{mg}\right.$ TEAC $\left.100 \mathrm{~g}^{-1}\right)$ and hydroethanolic $\left(3800.00 \pm 303.05 \mathrm{mg}\right.$ TEAC $\left.100 \mathrm{~g}^{-1}\right)$ extract from root presented non-significant difference $(p>0.05)$ by DPPH assay. Using water as solvent, root and leaf presented non-significant difference $(p>0.05)$ by DPPH, ABTS and FRAP analyses. Pearson's correlation coefficients (Table 4) shows that all antioxidant analysis presented significant correlation to $p<0.05$ and $p<0.01$. Thus, higher correlation coefficient was obtained, comparing root (DPPH/ABTS (0.97), DPPH/FRAP (0.87) and ABTS/FRAP (0.95)), and leaf (DPPH/ABTS (1), DPPH/FRAP (0.96) and ABTS/FRAP (0.98)).

According to Table 4, the Pearson's correlation coefficients on root and leaf of Rumex obtusifolius presented statistical difference $(p<0.05$ and $p<0.01)$. This fact show that all bioactive compounds (TPC, TFC and TF) analyzed in this study presented a significant correlation with antioxidant capacity (DPPH, ABTS and FRAP). The lower coefficient obtained was 0.92 (92\%) between TF and FRAP (root). Other studies also demonstrated high Pearson's correlation coefficients in vegetables extracts between bioactive compounds and antioxidant capacity. (Sganzerla et al., 2018; Thilakarathna and Rupasinghe, 2012; Vasco et al., 2008).

Using multivariate analysis was possible to discriminate the extracts of Rumex obtusifolius. Cluster Analysis (CA) technique (complete linkage using Euclidean distances) was used to examine the extraction of bioactive compounds and antioxidant activity in root and leaf Rumex obtusifolius. CA 


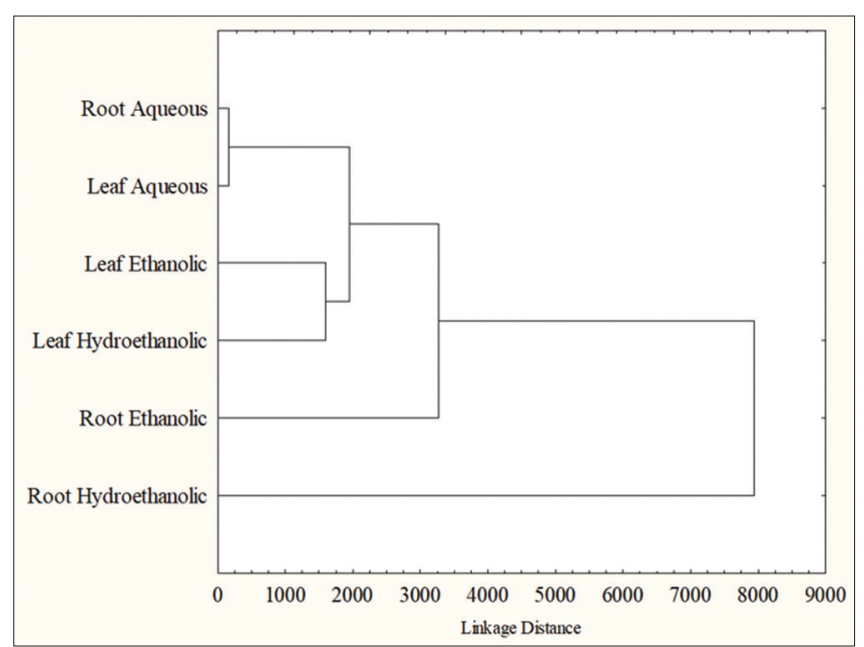

Fig 2. Cluster analysis to root and leaf extracts of Rumex obtusifolius.

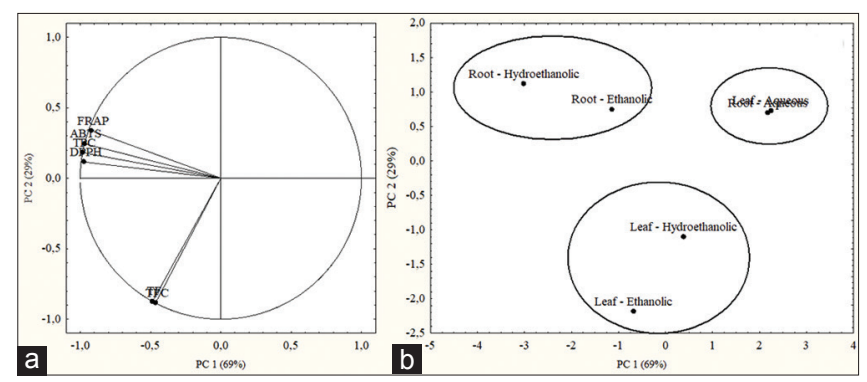

Fig 3. (a) Variable projection distribution to root and leaf extracts of Rumex obtusifolius. (b) Principal component analysis to root and leaf extracts of Rumex obtusifolius.

demonstrates (Fig. 2) that root in hydroethanolic extract presents a little similarity compared to other samples. However, a group with high interaction was joined by root and leaf in aqueous extracts; and leaf on ethanolic and hydroethanolic extracts presented a similarity behavior by CA. In the principal component analysis (Fig. 3), the PC $1(69 \%)$ explained most of the variability and PC 2 explained just $29 \%$. In total, a representative value of the data was explained by PCA (98\%). CA and PCA presented a similarity in the group classification. Hydroethanolic and ethanolic root extracts presented higher content of antioxidant activity (DPPH, ABTS and FRAP assay) and phenolic compounds, and this fact is observed in variable projection (Fig. 3a) and samples are in a square based on these variables (Fig. 3b). However, hydroethanolic and ethanolic leaf extracts were discriminated by the variables total flavonoids and flavonols compounds.

\section{CONCLUSION}

Rumex obtusifolius is a plant that can be easily founded worldwide. The vegetable can be considered as a good source of nutritional components necessary for human diet, such as lipids, proteins and carbohydrates. Moreover,
Rumex obtusifolius presents a great source of bioactive compounds (phenolic, flavonoids and flavonols) with high antioxidant activity in vitro. Evaluating the extraction of bioactive compounds, it was possible to determine that the best solvent tested in this study was the hydroethanolic extract to root and ethanolic extract to leaf.

\section{Author contributions}

In general, all authors contributed equally to the planning and execution of the research. W.G. Sganzerla performed the research, analyzed the data, conducted the statistical process and wrote the paper; R. Schmit and M.D. Melo collected the samples and performed the research; M.S. Azevedo supported the design of the study and conducted the statistical process; P.I. Ferreira collected the samples, performed the research, included the plant in the herbarium and was the responsible to the number of the voucher corresponding to the taxonomic classification. A.P.L. Veeck and J.P. Ferrareze designed the study, corrected the manuscript and assumed the responsibility for the final content. All authors have read and approved the final manuscript.

\section{REFERENCES}

AOAC Association of Official Analytical Chemistry. 2006. Official Methods of Analysis of the Association of Official Analytical Chemistry. $17^{\text {th }}$ ed., Association of Official Analytical Chemistry, Washington, DC.

Arnous, A., D. Makris and P. Kefalas. 2002. Correlation of pigment and flavanol content with antioxidant properties in selected aged regional wines from Greece. J. Food Compos. Anal. 15: 655-665.

Barreira, T. F., G. X. P. Filho, V. C. C. Rodrigues, F. M. C. Andrade, R. H. S. Santos, S. E. Priore and H. M. Pinheiro-Santana. 2015. Diversidade e equitabilidade de plantas alimentícias não convencionais na zona rural de Viçosa, Minas Gerais, Brasil. Rev. Bras. Plantas Med. 17: 964-974.

Benvenuti, S., M. Macchia and S. Miele. 2001. Light, temperature and burial depth effects on Rumex obtusifolius seed germination and emergence. Weed Res. 41: 177-186.

Benzie, I. F. F. and J. J. Strain. 1996. The ferric reducing ability of plasma (FRAP) as a measure of "antioxidant power": The FRAP assay. Anal. Biochem. 239: 70-76.

Bharucha, Z. and J. Pretty. 2010. The roles and values of wild foods in agricultural systems. Philos. Trans. R. Soc. B Biol. Sci. 365: 2913-2926.

Bligh, E. G. and W. J. Dyer. 1959. A rapid method of total lipid extraction and purification. Can. J. Physiol. Pharmacol. 37: 911-917.

Brand-Williams, W., M. E. Cuvelier and C. Berset. 1995. Use of a free radical method to evaluate antioxidant activity. LWT Food Sci. Technol. 28: 25-30.

Campos, D., R. Chirinos, L. G. Ranilla and R. Pedreschi. 2018. Bioactive potential of andean fruits, seeds, and tubers. Adv. Food Nutr. Res. 84: 287-343.

Carneiro, F. M., M. J. P. da Silva, L. L. Borges, L. C. Albernaz and J. D. P. Costa. 2014. Tendências dos estudos com plantas medicinais no Brasil. Rev. Sapiência Soc. Saberes Prát. Educ. 3: 44-75. 
Chivenge, P., T. Mabhaudhi, A. Modi and P. Mafongoya. 2015. The potential role of neglected and underutilised crop species as future crops under water scarce conditions in Sub-Saharan Africa. Int. J. Environ. Res. Public Health. 12: 5685-5711.

Clerici, M. T. P. and L. B. Carvalho-Silva. 2011. Nutritional bioactive compounds and technological aspects of minor fruits grown in Brazil. Food Res. Int. 44: 1658-1670.

Da Silva, J. K., C. B. B. Cazarin, T. C. Colomeu, Â. G. Batista, L. M. M. Meletti, J. A. R. Paschoal, S. Jr. Bogusz, M. F. Furlan, F. G. R. Reyes, F. Augusto, M. R. Jr. Maróstica and R. de Lima Zollnerb. 2013. Antioxidant activity of aqueous extract of passion fruit (Passiflora edulis) leaves: In vitro and in vivo study. Food Res. Int. 53: 882-890.

Filho, M. N., A. Pelissari, H. S. Koehler, J. C. Bassetti, M. Muraro, M. Kerkhoff and A. Sphyra. 2014. Controle químico de plantas daninhas utilizando diferentes pontas de pulverização. Sci. Agrar. 15: 33-37.

García-Herrera, P., M. C. Sánchez-Mata, M. Cámara, V. FernándezRuiz, C. Díez-Marqués, M. Molina and J. Tardío. 2014. Nutrient composition of six wild edible Mediterranean Asteraceae plants of dietary interest. J. Food Compos. Anal. 34: 163-170.

Gulshan, A. B., A. A. Dasti, S. Hussain, M. I. Atta and M. Amin-ud-Din. 2012. Indigenous uses of medicinal plants in rural areas of Dera Ghazi Khan, Punjab, Pakistan. J. Agric. Biol. Sci. 7: 750-762.

Harshaw, D., L. Nahar, B. Vadla, G. Saif-E-Naser and S. Sarker. 2010. Bioactivity of Rumex obtusifolius (Polygonaceae). Arch. Biol. Sci. 62: 387-392.

Holm, L. G., D. L. Plucknett, J. V. Pancho and J. P. Herberger. 1977. The World's Worst Weeds: Distrbution and Biology, The Eastwest Center by the University Press of Hawaii, United States of America, Honolulu.

Instituto Adolfo Lutz. 2008. Métodos Físico-químicos Para Análise de Alimentos, Instituto Adolfo Lutz, Brazil, São Paulo.

Kinupp, V. F. and H. Lorenzi. 2014. Plantas Alimentícias Não Convencionais (PANC) no Brasil: Guia de Identificação, Aspectos Nutricionais e Receitas llustradas.

Kinupp, V. F. and I. B. I. Barros. 2007. Riqueza de plantas alimentícias não-convencionais na região metropolitana de porto alegre, Rio Grande do Sul. Rev. Bras. Biociências. 5: 63-65.

Kumaran, A. and R. J. Karunakaran. 2007. In vitro antioxidant activities of methanol extracts of five phyllanthus species from India. LWT Food Sci. Technol. 40: 344-352.

Liu, R. H. 2004. Potential synergy of phytochemicals in cancer prevention: Mechanism of action. J. Nutr. 134: 3479-3485.

Mohammed, A. S. M., M. M. R. Khan, S. A. Jabin, N. Abedin, M. F. Islam and B. Shaha. 2016. Nutritional quality and safety aspects of wild vegetables consume in Bangladesh. Asian Pac. J. Trop. Biomed. 6: 125-131.

Oladeji, O. and F. Adelowo. 2017. Plant phenolic compounds and health benefits. Commun. Plant Sci. 7: 20-26.
Oliveira, V. B., L. T. Yamada, C. W. Fagg and M. G. L. Brandão. 2012. Native foods from Brazilian biodiversity as a source of bioactive compounds. Food Res. Int. 48: 170-179.

Pereira, D., P. Valentão, J. Pereira and P. Andrade. 2009. Phenolics: From chemistry to biology. Molecules. 14: 2202-2211.

Re, R., N. Pellegrini, A. Proteggente, A. Pannala, M. Yang and C. Rice-Evans. 1999. Antioxidant activity applying an improved ABTS radical cation decolorization assay. Free Radic. Biol. Med. 26: 1231-1237.

Rocha, W. S., R. M. Lopes, D. B. Silva, R. F. Vieira, J. P. Silva and T. S. Agostini-Costa. 2011. Compostos fenólicos totais e taninos condensados em frutas nativas do cerrado. Rev. Bras. Fruticultura. 33: 1215-1221.

Rufino, M. S. M., R. E. Alves, E. S. de Brito, J. Pérez-Jiménez, F. Saura-Calixto and J. Mancini-Filho. 2010. Bioactive compounds and antioxidant capacities of 18 non-traditional tropical fruits from Brazil. Food Chem. 121: 996-1002.

Sganzerla, W. G., P. C. Beling, J. P. Ferrareze, R. A. Komatsu, M. R. Nunes and A. P. L. Veeck. 2018. Nutritional, physicochemical and antimicrobial properties of uvaia pulp (Eugenia pyriformis Cambess). Commun. Plant Sci. 8: 1-7.

Šola, I., M. Stipaničev, V. Vujčić, B. Mitić, A. Huđek and G. Rusak. 2018. Comparative analysis of native crocus taxa as a great source of flavonoids with high antioxidant activity. Plant Foods Hum. Nutr. 73: 189-195.

Spencer, P., S. Sivakumaran, K. Fraser, L. Y. Foo, G. A. Lane, P. J. B. Edwards and L. P. Meagher. 2007. Isolation and characterisation of procyanidins from Rumex obtusifolius. Phytochem. Anal. 18: 193-203.

St'astná, P., L. Klimes and J. Klimesová. 2010. Biological flora of Central Europe: Rumex alpinus L. Perspect. Plant Ecol. Evol. Syst. 12: 67-79.

Storck, C. R., G. L. Nunes, B. B. Oliveira and C. Basso. 2013. Folhas, talos, cascas e sementes de vegetais: Composição nutricional, aproveitamento na alimentação e análise sensorial de preparações. Ciên. Rural. 43: 537-543.

Swain, T. and W. E. Hillis. 1959. The phenolic constituents of Prunus domestica I-The quantitative analysis of phenolic constituents. J. Sci. Food Agric. 10: 135-144.

Thilakarathna, S. H. and H. P. V. Rupasinghe. 2012. Antiatherosclerotic effects of fruit bioactive compounds: A review of current scientific evidence. Can. J. Plant Sci. 92: 407-419.

Vasas, A., O. Orbán-Gyapai and J. Hohmann. 2015. The genus rumex: Review of traditional uses, phytochemistry and pharmacology. J. Ethnopharmacol. 175: 198-228.

Vasco, C., J. Ruales and A. Kamal-Eldin. 2008. Total phenolic compounds and antioxidant capacities of major fruits from Ecuador. Food Chem. 111: 816-823.

Zhishen, J., T. Mengcheng and W. Jianming. 1999. The determination of flavonoid contents in mulberry and their scavenging effects on superoxide radicals. Food Chem. 64: 555-559. 